\title{
Histochemical and immunohistochemical evaluation of angiogenesis in rabbits (Oryctolagus cuniculus) submitted to skin grafts associated with platelet-rich plasma ${ }^{1}$
}

\author{
Josiane M. Pazzini ${ }^{2 *}$, Eduardo L. Serafim² ${ }^{2}$ Fátima Gärtner ${ }^{3}$, Irina Amorim³ ${ }^{3}$, Fátima \\ Faria $^{3}$, Alexandra Rêma ${ }^{3}$, Paola C. Moraes ${ }^{2}$ and Andrigo B. De Nardi ${ }^{2}$
}

\begin{abstract}
Pazzini J.M., Serafim E.L., Gärtner F., Amorim I., Faria F., Rêma A., Moraes P.C. \& De Nardi A.B. 2017. Histochemical and immunohistochemical evaluation of angiogenesis in rabbits (Oryctolagus cuniculus) submitted to skin grafts associated with platelet-rich plasma. Pesquisa Veterinária Brasileira 37(12):1519-1525. Departamento de Clínica e Cirurgia Veterinária, Faculdade de Ciências Agrárias e Veterinárias, Universidade Estadual Paulista, Campus Jaboticabal, Via de Acesso Paulo Donatto Castellane s/n, Jaboticabal, SP 14884-900, Brazil. E-mail: josipazzini@hotmail.com

Histochemical staining consists of a set of specific chemical reactions of structures or tissue-endogenous substances. Immunohistochemistry allows verification of proteins in tissues related to biological and pathological factors. The standardization of methods to assess angiogenesis resulting from formation of new blood vessels in procedures with stimulants is important to facilitate the implementation of research as well as to assist interpretation of data. In rabbits some markers of angiogenesis antibodies in the skin are not standardized because of cross-reactions that may occur because the antibodies are made from such animals.The aim of this study was to analyze the immunohistochemical methods through dyes and immunohistochemical markers angiogenesis in rabbits (Oryctolagus cuniculus) having undergone reconstructive surgery with skin grafts associated with plasma angiogenesis stimulator rich in platelets, in order to evaluate which method would be better to visualize the vessels, as well as to evaluate which antibody would promote better immunostaining, and find the differences between the methods and to standardize the methodology to be applied in experiments using rabbits. Sixteen rabbits were used, split into two groups of eight animals: Gprp (plasma rich in platelets) and Gc (control, saline solution, $9 \%$ ). The same technique of reconstructive surgery using graft mesh was performed on each rabbit. The groups differed only in the application of platelet-rich plasma before the surgical wound synthesis. Samples for evaluation of angiogenesis were collected 15 days after the surgical procedure. The dyes Hematoxylin \& Eosin and Masson's Trichrome were used in the histochemical study to evaluate vascular proliferation. Markers CD31, CD34 and Caveolin-1 was used for the immunohistochemical study. The evaluation between the groups (Gprp and Gc) in regard to the categorical variable (vascular proliferation intensity) used the Kruskal-Wallis test with p values equal to or less than 0.05 being considered significant. The immunohistochemistry was subjected to analysis of variance for a completely randomized design, with two groups and five repetitions (medium) and 5\% significance
\end{abstract}

\footnotetext{
${ }^{1}$ Received on November 2, 2016.

Accepted for publication on March 21, 2017.

${ }^{2}$ Departamento de Clínica e Cirurgia Veterinária, Faculdade de Ciências Agrárias e Veterinárias (FCAV), Universidade Estadual Paulista (Unesp), Via de Acesso Professor Paulo Donato Castellane s/n, Jaboticabal, SP 14884-900, Brasil. Pesquisa de doutorado com apoio da Capes, Programa de Doutorado Sanduíche no exterior e Cnpq (PDSE, Processo 147728/2016-9). E-mails: josipazzini@hotmail.com, eduar-
}

doluis.serafim@gmail.com, pcastromoraes@yahoo.com.br, andrigobarboza@yahoo.com.br; *Autora para correspondência: josipazzini@ hotmail.com

${ }^{3}$ Departamento de Patologia Veterinária, Instituto de Ciências Biomédicas Abel Salazar (ICBAS), Universidade do Porto (UP), Rua Jorge Viterbo Ferreira 228, Porto, 4050-313, Portugal. E-mails: fgartner@ipatimup. pt, irinamorim@hotmail.com, fatimafaria10@yahoo.com.br, alexandra. rema@gmail.com 
level. Multiple comparison of groups resulted in the Tukey test $(\mathrm{p}=0.05)$ used. The amount of vascular proliferation assessed by histochemical method HE and Masson's Trichrome was found to be a significant variable in Gprp when compared with group Gc. When evaluating the methods used, there was no significant difference. There was no difference in the three markers which were used for correlating microvessels; however, there was more intense staining of vessels when Caveolin-1 Antibody was used. This caused intense marking of the capillaries and small vessels, as well as of larger vessels. When using CD31 and CD34, the same was observed, but it was not as intense as with Caveolin-1; though some cases showed sincere and discreet marking. The results of this study demonstrated that the histochemical methods performed are effective for semi-quantitative assessment of angiogenesis. The immunohistochemical comparison of Caveolin-1, CD31, and CD34 as markers of angiogenesis in rabbits showed that both antibodies could immunostain the newly formed vessels; but the Caveolin-1 showed better immunostaining in small and medium-sized vessels, as well as a minor presence in the background. Although not specific markers for angiogenesis, they can be used as immunohistochemical markers of vascular endothelium in rabbits.

INDEX TERMS: Angiogenesis, skin grafts, immunohistochemistry, histochemistry, rabbit.

RESUMO.- [Histoquímica e imunohistoquíca na avaliação da angiogênese em coelhos submetidos ao emprego de enxertos cutâneos associado com plasma rico em plaquetas.] Colorações histoquímicas consistem de um conjunto de reações químicas específicas das estruturas ou substâncias endógenas do tecido. Logo a Imunohistoquímica permite observar proteínas presentes nos tecidos relacionadas com fatores determinantes do comportamento biológico e patológico. A padronização dos métodos que avaliam a angiogênese decorrente de procedimentos que utilizam substâncias estimulantes à formação de novos vasos são importantes, a fim de facilitar a execução das pesquisas, bem como auxiliar na interpretação dos dados, visto que em coelhos alguns anticorpos marcadores de angiogênese na pele ainda não são padronizadas em virtude das reações cruzadas que podem ocorrer devido aos anticorpos serem confeccionados a partir de tais animais. Objetivou-se analisar os métodos histoquímicos por meio das colorações e imunohistoquímicas com marcadores de angiogênese em coelhos (Oryctolagus cuniculus) submetidos ao emprego de enxertos cutâneos associado com estimulador de angiogênese plasma rico em plaquetas, a fim de avaliar qual método seria melhor para visualização dos vasos, bem como avaliar qual anticorpo promoveria melhor imunomarcação, buscando-se assim encontrar a diferenças entre os métodos e padronizar a metodologia a ser aplicada em experimentos que utilizem coelhos. Utilizou-se 16 coelhos, separados em dois grupos com oito animais, compreendendo os grupos Gprp (plasma rico em plaquetas) e Gc (controle, solução fisiológica $0,9 \%$ ). Em todos os animais foi realizada a mesma técnica de cirurgia reconstrutiva de enxertia do tipo malha, os grupos diferiram apenas a aplicação do plasma rico em plaquetas antes da síntese da ferida cirúrgica. As amostras para avaliação da angiogênese foram coletadas após 15 dias do procedimento cirúrgico. Utilizou-se no estudo histoquímico as colorações Hematoxilina \& Eosina e Tricrômico de Masson para avaliação da proliferação vascular, e os anticorpos CD31 e CD34 e Caveolina - 1 para avaliação imunohistoquímica. A comparação entre os grupos (Gprp e Gc) em relação à variável categórica (intensidade de proliferação vascular) foi utilizado o teste de Kruskal-Wallis, com valores de p iguais ou inferiores a 0,05 foram considerados significativos. Os dados imuno-histoquímico foram submetidos à análise de variância para um delineamento inteiramente ao acaso, com 2 grupos e 5 repetições (médias) e nível de significância de 5\%. Nas comparações múltiplas das médias dos grupos, utilizou-se o teste de Tukey $(\alpha=0,05)$. A intensidade de proliferação vascular avaliada pelo método histoquímico HE e Tricômico de Masson encontrou-se que tal variável foi significativa no Gprp, quando comparado com o Gc. Avaliando os métodos utilizados não houve diferença significativa. A contagem microvascular (MVC) realizada com os diferentes marcadores (Caveolina-1, CD31 e CD34) foi significativa no Gprp. Correlacionando a contagem microvascular dos três marcadores utilizados não houve diferença significativa, no entanto observou-se marcação mais intensa dos vasos utilizando o anticorpo Caveolina-1, sendo intensa a marcação dos capilares, vasos de pequeno calibre, bem como em vasos maiores. Nas avaliações de CD31 e CD34 observou que houve imunomarcação dos vasos, porém não foi intensa como a Caveolina-1, alguns casos apresentaram fundo, bem como marcação discreta. Os resultados encontrados neste estudo evidenciaram os métodos histoquímicos são eficazes para avaliação semiquantitativa da angiogênese. A comparação imunohistoquímicas da Caveolina-1, CD31 e CD34 como marcadores de angiogênese em coelhos evidenciaram que ambos os anticorpos são capazes de imunomarcar os vasos neoformados, porém a Caveolina-1 apresentou melhor imunomarcação de vasos de pequeno e médio calibre, bem como menor presença de fundo, embora não seja um marcador específico para angiogênese pode ser utilizada como marcador imunohistoquímico de endotélio vascular em coelhos.

TERMOS DE INDEXAÇÃO: Angiogênese, enxertos cutâneos, imunohistoquímica, histoquímica, coelho.

\section{INTRODUCTION}

According to Pazzini et al. (2016), the use of gel with platelet-rich plasma in the subcutaneous tissue of the wound recipient bed provides excellent results when compared 
with saline, indicating that the intense vascular proliferation is related to the use of PRP, suggesting the ability of this compound to promote angiogenesis at the application site Skin grafts are thoroughly studied to be presently effective in correcting wounds on members; however, this method is seldom used due to the time it takes for the formation of granulation tissue (Pazzini \& Moraes 2015), by a segment of the epidermis and dermis being completely removed from the donor region and transferred to the receptor site without the presence of vascular pedicle (Hedlund 2008) These cases are more prone to complications, such as necrosis after surgery.

However, problems encountered related to neovascularization in surgical procedures are targets of studies in various medical areas, and the platelet-rich plasma (PRP) has led to many studies reducind complications caused by the lack of angiogenesis (Vendramin et al. 2006).

Thus, the resources used to assess and quantify the angiogenesis are by histochemical and immunohistochemical methods, which are also employed in situations as prognostic markers as well as for research purposes (Weidner et al. 1991).

Histochemical stains consist of a set of specific chemical reactions of endogenous substances or structures of the tissue. Through this, viewing microorganisms, carbohydrates, connective tissue, amyloid materials and lipids as well as pigments is made possible.

In case, Immunohistochemistry allows for the observation ofproteins in related tissues with determinants of biological and pathological behavior. Through specific reactions between antigen and antibody, the presence of fluorescence or color in the microscopic analysis (Bancroft et al. 2012) can also be noted.

Thus, to evaluate tissue angiogenesis it is possible to use stains such as HE (Hematoxylin and Eosin) and Masson's Trichrome, but they are not specific stains for vessel identification. There are also immunohistochemical markers of vascular endothelium that are specific for angiogenesis evaluation, being the most used for this purpose Factor VIII, CD31, CD34, Vegf and CD105 (Bancroft et al. 2012).

That said, in the evaluation of angiogenesis in tissues, the primary dyes used are HE (hematoxylin \& eosin) and Masson's trichromic. The immunohistochemical markers most commonly used vascular endothelium for this purpose such as factor VIII, CD 31, CD34, VEGF and CD 105 (Bancroft et al. 2012), but other endothelial markers for quantification of vessels, such as Caveolin-1 have been used. Nevertheless, an antibody used to identify the cytoplasm, membrane and endothelium presents successful reports of its use for assessing angiogenesis. Serafim (2016) indicates its use and success as an angiogenesis marker in skin fragments of rabbits undergoing reconstructive surgery.

However, there still is not a particular standard method for assessing angiogenesis, especially in laboratory animals, which are used as an experimental model in veterinary medicine as well as in human medicine. Thus, research such as this is necessary to evaluate methods of identifying the formation of new vessels resulting from procedures using stimulants angiogenesis to facilitate the implementation of the investigation, as well as aid in the interpretation of the data.

The purpose of this study was to analyze the immunohistochemical methods through dyes and immunohistochemical markers of angiogenesis in rabbits (Oryctolagus cuniculus) having undergone skin grafts associated with platelet-rich plasma, an angiogenesis stimulator. In order to evaluate which method would be better to visualize the vessels, as well as to evaluate which antibody would promote better immunostaining, in order to find the differences between the methods and to standardize the methodology to be applied in experiments using rabbits

\section{MATERIALS AND METHODS}

Ethics statement. This study was approved by the Ethics Committee on Animal Use (CEUA) of the Universidade Estadual Paulista (UNESP), Jaboticabal Campus (Protocol number 11767/14).

Patient selection. Surgical procedures of this study were performed in the Veterinary Hospital "Governador Report Natel" of the Faculty of Agricultural and Veterinary Sciences (FCAV), Universidade Estadual Paulista (UNESP), Jaboticabal Campus. The slides destined to histological analysis were made in Veterinary Pathology Laboratory of the University of Porto, Portugal.

The experimental model used to perform the reconstructive surgery was the rabbit (Oryctolagus cuniculus). 16 rabbits White New Zealand were used, with about 60 days of age, females and an average weight of $3 \mathrm{~kg}$ from producer specialized in the creation of the species. The rabbits were kept at the biotery Postgraduate Course in Veterinary Surgery as recommended by the National Council for Animal Experimentation Control (CONCEA).

The animals were separated into two groups of eight animals: the GPRP (rich plasma gel platelets) group and Gc (saline solution, $9 \%$ ) group. Overall, the same technique of reconstructive surgery grafting mesh type was performed on the animals. The groups differed only in the application of platelet-rich plasma before the surgical wound synthesis.

Specimens for evaluation of angiogenesis were collected 15 days after the surgical procedure. The animals were euthanized with propofol at a dose of $10 \mathrm{mg} / \mathrm{kg}$, administered intravenously to deepen the anesthesia, and the infusion of potassium chloride was undertaken immediately according to the ethical principles of animal testing recommended by the Council National Animal Experimentation Control (CONCEA).

Then, the wounds were excised with a margin of $1 \mathrm{~cm}$ intact skin around the $16 \mathrm{~cm}^{2}$ lesion. The fascia was at the depth limit. Each fragment was individually identified as fixed on the paper card and placed in a $10 \%$ formalin solution ${ }^{4}$. After 48 hours, the solution was replaced by $70 \%$ alcohol $^{5}$. Then, the material was referred to the Veterinary Pathology Laboratory at the University Porto, Portugal, for making the slides for microscopic evaluation.

The samples were processed in a conventional histological processing routine, embedded in paraffin blocks, and done with a realization of histological sections. These were cut into microtome ${ }^{6}$ with a thickness of $2 \mu \mathrm{m}$.

Hematoxylin \& Eosin were used to evaluate the vascular proliferation in the Histocheminal study. For the immunohistochem-

\footnotetext{
${ }^{4}$ Formol a $10 \%$ tamponado, Indalabor, Dores do Indaiá, Minas Gerais, Brasil.

${ }^{5}$ Alcool 70\%, Tupi, Ibaté, São Paulo, Brasil.

${ }^{6}$ Micrótomo rotativo RM2036, Leica Biosystems, Carnaxibe, Portugal.
} 
Table 1. Antibodies used for immunohistochemistry cutaneous tissues of rabbits conducted at Veterinary Pathology Laboratory, University of Porto, Portugal, 2016

\begin{tabular}{|c|c|c|c|c|c|c|c|}
\hline Maker & Clone & Supplier & Dilution & Antigenic recovery & $\begin{array}{c}\text { Incubation } \\
\text { period }\end{array}$ & $\begin{array}{l}\text { Detection } \\
\text { system }\end{array}$ & $\begin{array}{l}\text { Positive } \\
\text { control }\end{array}$ \\
\hline $\begin{array}{l}\text { CD31 } \\
\text { mo323 }\end{array}$ & $\begin{array}{c}\text { Monoclonal, } \\
\text { jc70a }\end{array}$ & Dako & $1: 50$ & $\begin{array}{c}\text { Pepsina porcine gastric } \\
\text { mucosa, Sigma Life Science, } \\
\text { United Kingdom }\end{array}$ & 45 minutes & $\begin{array}{l}\text { Polymer } \\
\text { detection } \\
\text { systems }\end{array}$ & $\begin{array}{l}\text { Rabbit } \\
\text { normal } \\
\text { skin }\end{array}$ \\
\hline $\begin{array}{l}\text { CD34 } \\
550390\end{array}$ & $\begin{array}{c}\text { Monoclonal, } \\
581\end{array}$ & $\begin{array}{c}\text { BD } \\
\text { pharmigen }\end{array}$ & $1: 10$ & $\begin{array}{c}\text { Pepsina porcine gastric } \\
\text { mucosa, Sigma Life Science, } \\
\text { United Kingdom }\end{array}$ & 45 minutes & $\begin{array}{l}\text { Polymer } \\
\text { detection } \\
\text { systems }\end{array}$ & $\begin{array}{c}\text { Rabbit } \\
\text { normal } \\
\text { skin }\end{array}$ \\
\hline $\begin{array}{l}\text { Caveclin-1 } \\
51040\end{array}$ & $\begin{array}{c}\text { Policlonal, } \\
\text { anti-Caveolin }\end{array}$ & $\begin{array}{c}\text { BD } \\
\text { pharmigen }\end{array}$ & $1: 500$ & - & 45 minutes & $\begin{array}{l}\text { Polymer } \\
\text { detection } \\
\text { systems }\end{array}$ & $\begin{array}{l}\text { Rabbit } \\
\text { normal } \\
\text { skin }\end{array}$ \\
\hline
\end{tabular}

ical study, a panel of antibodies specific for several antigens was applied (Table 1). The glass slides was previously cleaned and degreased, and prepared with prepared with organosilane-based adhesive (3-aminopropyl triethoxysilane, C.O. Sigma Chemical, USA). Novolink ${ }^{\text {tm }}$ Polymer Detection Systems was used according to the manufacturer's instructions.

Methods of data interpretation. The analysis of histological sections was performed by the same pathologist without prior knowledge of the identification of the groups $(F G)$. Histological evaluation of tissue was examined under an optical microscope ${ }^{7}$ at 400x magnification. The photomicrographs were held on the NIS program, Nikon Imaging Software Elements version 30.4 NIS program, Nikon Imaging Software Elements version 4.30.

The data obtained using Hematoxylin \& Eosin, as well as using Masson's trichrome were determined by the semiquantitative and quantitative method. The semiquantitative technique of vascular proliferation was determined according to the intensity of the vessels were found. The findings were translated into quantitative variables by index assignment for histological findings, as recommended by Garros et al. (2006) and recorded on individual records for each animal.

The angiogenic indexes for Hematoxylin \& Eosin, Masson's trichrome, Caveolina-, CD31 and CD34 were determined by microvessel counting technique (MVC) as done under Maeda et al. (1995). The areas were analyzed with the largest number of vessels in the depth of the lesion. Any endothelial cell or cell groupstained positively separate from adjacent microvessel, healthy cells, and other connective tissue elements, were regarded as a unitary vessel, and also, the vessels containing lumen. The vessels containing lumen were considered the same way. Microvessel counting was carried out in five fields, previously selected at a high vascular density, with the microscope set to a magnification of 400x. The microvessel count (MVC) was determined twice by a single evaluator at two different times and was expressed as a mean number of vessels in each case studied.

Statistical analysis. Comparison between groups (Gprp and Gc) from the categorical variable (vascular proliferation intensity) was used the Kruskal-Wallis test with $p$ values equal to or less than $0.05(p<0.05)$ were considered significant. For the analysis was used Npar1way procedure computer program SAS (SAS 9.1, SAS Institute, Cary. NC, USA), was used for the anaylsis as well as the GraphPad Prism program, Version 4.00.

The immunohistochemical data were submitted to analysis of variance for a completely randomized design, with two groups with five repetitions (medium) at a 5\% significance level. Multiple comparisons of group called for our using the Tukey test $(\alpha=0.05)$. For this analysis, we used the General Linear Models Procedure (GLM) of the SAS computer software (SAS 9.1, SAS Institute, Cary. NC, USA).

\footnotetext{
${ }^{7}$ Microscópio Nikon eclipse- E200.
}

\section{RESULTS AND DISCUSSION}

The proliferation of vascular were determined by the semiquantitative and quantitative method.by usingHE and Masson's trichrome has been found to be a significant variable in group GPRP ( $\mathrm{p}=0.01)$ (Fig.1A) when compared with the control group (Fig.1B). The evaluation of the methods used concluded that there was no significant difference $(\mathrm{p}>0.05)$.

Low cost and ability to demonstrate various structures are assigned to features in HE staining, which is frequently used in routine laboratories (Bancroft et al. 2012). Masson's trichrome is also used, but to a lesser extent because of its longer preparation time and how it requires different reagents compared to HE; its purpose is to highlight the types of surrounding tissue and to make it possible to distinguish blood vessels from other structures (Bancroft et al. 2012).

The characteristics of the HE and Masson's trichrome were observed during microscopic analysis in this study as described in the literature (Bancroft et al. 2012). One can distinguish the pré-blood vessels apparently formed using Masson's Trichrome, as is evidenced from other structures whenfacilitating the analysis; however, HE has also been observed in the same structures, only requiring further attention during the review because the vessels are not evidencing much compared with Masson's Trichrome.

For semiquantitative evaluation of the vessels, the HE and Masson trichrome staining were chosen to be used because of there being described few methods for assessing angiogenesis in the skin of rabbits. HE staining alone is commonly used for this purpose. Thus, the immunohistochemical methods and analyses performed in this study are in agreement with Reis (2015), and Serafim (2016), who used such dyes in a semiquantitative evaluation of blood vessels in rabbits fragments undergoing reconstructive surgery since they obtained good results. However, in this study, the quantitative technique for vessel counting using $\mathrm{HE}$ and masson trichrome was also performed, in order to evaluate the difference between the methods $(p=0,05)$. Although there was no significant difference between the two methods of analysis, it is recommended to use the quantitative technique because of its accuracy.

Microvessel count (MVC) was performed with different markers (Caveolin-1, CD31, and CD34) and was significant 


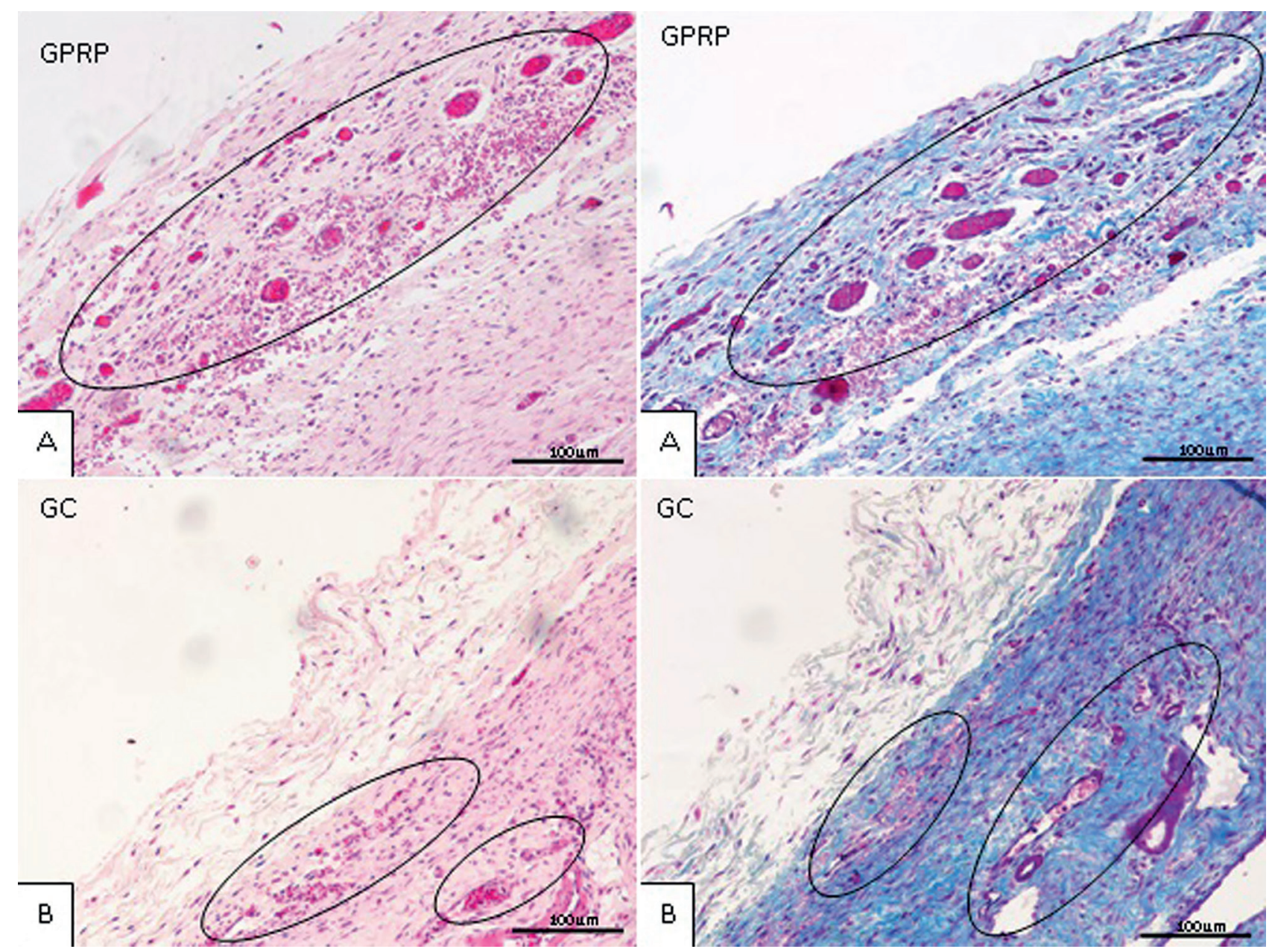

Fig.1. Histologic aspect of vascular proliferation in rabbits (Oryctolagus cuniculus). Photomicrograph perspective of animal dermis submitted to the reconstructive surgery procedure at the Veterinary Hospital of the Faculty of Agricultural and Veterinary Sciences (FCAV) of Unesp, Jaboticabal Campus, 2015. (A) Accentuated presence of neovascularization in circumscribed area in GPRP. (B) Discreet presence of neovascularization in circumscribed area in Gc. HE and Masson's trichrome respectively, 100x.

at GPRP ( $\mathrm{p}=0.01$ ) (Fig.2A) compared with the control group (Fig.2B), averaging vessels 56.5 and 20.9 respectively appearing in groups. When correlating microvessel count of the three markers there was no significant difference ( $p>0.05$ ). However, there was more intense staining of vessels. When using Caveolin-1 Antibody the marking of the capillaries, small vessels were intense, as well as inlarger vessels. When assessing the CD31 and CD34, marking of vessels were observed, but was not as intense as with Caveolin-1. Some cases showed background and discreet marking. The results of this study are similar to Serafim (2016), which reports success in using Caveolin-1 as a marker of angiogenesis in the skin fragements of rabbits undergoing reconstructive surgery.

According to Abbas et al. (2013), Caveolin-1 is an antibody used for identifying cytoplasm membrane and endothelium; it's not specific for angiogenesis. The results of this test were contrary to that as described in the literature (Abbas et al. 2013.) because of Caveolin - 1 showingintense immunolabeling of neovascularization, proving it to be an excellent marker of angiogenesis in the skin of rabbits.

Besides other specific markers being used to evaluate the angiogenic index as VEGF, CD 31, CD 34, CD105 and Factor VIII (Bancroft et al. 2012), in rabbits there is a restric- tion of some of these markers due to polyclonal antibodies being obtained from lab animals, especially rabbits and mice (Ball et al. 1990, Hay et al. 2002).

The specific markers of vascular endothelial (VEGF, CD 31, CD 34 and Factor VIII) obtained from rabbits are more susceptible to submit changes, such as cross reactions and false negatives, which can compromise the result. Changes often result in intense staining of various structures, intense presence of background, or no marking (Bancroft et al. 2012). The results of this study are in agreement with the literature, since when using specific markers for angiogenesis (Bancroft et al. 2012) CD34 and CD31 the presence of background in some samples was observed, and in individual cases occurred lighter markup of the vessel. Although it has not presented significant difference between the assessment of markers, the microvascular count of CD 31 and CD 34 required greater attention in order to avoid failure due to the fund's presence and the discrete markings. Although Caveolin-1 is not highly specific for vascular endothelium, the labeling in endothelial rabbit tissue was satisfactory when compared with other antibodies employed in this work, making it suitable for microvessel count in rabbits. These results are consistent with Serafim (2016). 

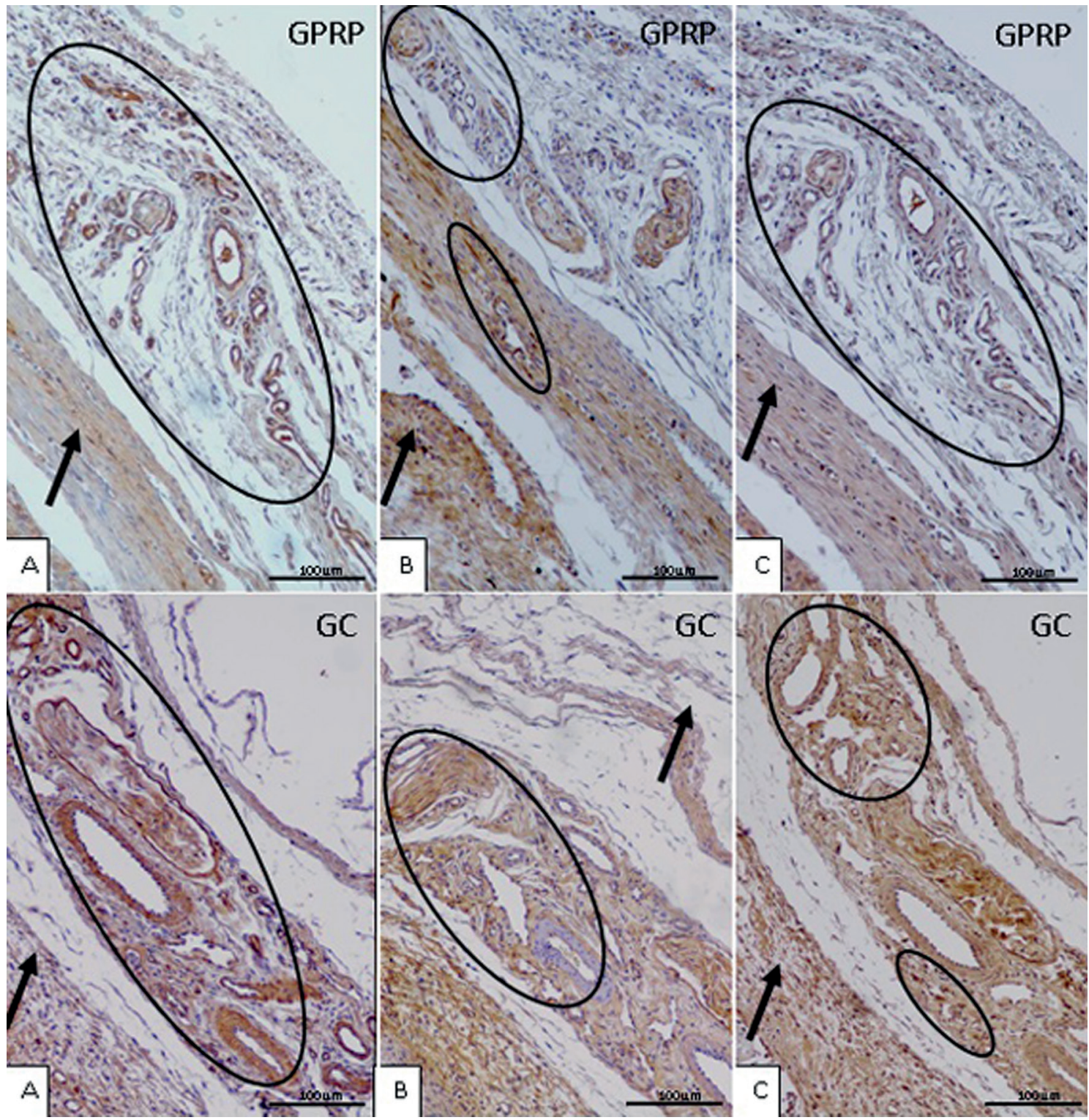

Fig.2. Histologic aspect of microvessel count (MVC) in rabbits (Oryctolagus cuniculus). Dermal photomicrography of rabbits submitted to the reconstructive surgery procedure at the Veterinary Hospital of the Faculty of Agricultural and Veterinary Sciences (FCAV) of Unesp, Jaboticabal Campus, 2015. (A) Presence accentuated neovascularization in circumscribed area in GPRP, noting the presence of background (arrow). (B) Discreet presence of neovascularization in circumscribed area in Gc, noting the presence of background (arrow). (C) Discreet presence of neovascularization in circumscribed area in Gc, noting the presence of background (arrow). Marker Caveolin-1, CD31, CD34, respectively. 100x.

\section{CONCLUSIONS}

The results of this study demonstrated the histochemistry methods performed with Hematoxylin and eosin as well as with Masson's Trichrome staining being useful for semi-quantitative assessment of angiogenesis, although there was not specific demand greater attention from the pathologist at the time of the analysis in order to avoid failures in counting; however we recommend using Masson's trichrome for histochemical evaluation of angiogenesis as it shows the vessels.

The immunohistochemical comparison of Caveolin-1, CD31, and CD34 as markers of angiogenesis in rabbits showed that both antibodies could immunolabel newly formed vessels, but the Caveolin-1 showed better immunolabeling of small and medium sized vessels and lower presence of background, being considered as immunohistochemical marker of vascular endothelium in rabbits.

Acknowledgements.- The authors are grateful to the Coordination of Improvement of Higher Education Personnel (CAPES) for the scholarship given to Josiane Morais Pazzini; Faculty of Agricultural and Veterinary Sciences of Jaboticabal (FCAV), Universidade Estadual Paulista (Unesp), for the structure and laboratory support; CAPES for the scholarship accorded in Brazil and Portugal (PDSE); the laboratory team at the University of Porto for supporting activities conducted.

\section{REFERENCES}

Abbas A.K., Kumar V., Fausto N. \& Aster J.C. 2013. Robbins \& Cotran Patologia, Bases Patológicas das Doenças: inflamação e reparo. Vol.2. 9a ed. Elsevier, Rio de Janeiro, p.29-74. 
Bancroft's J.D., Layton C. \& Suvarna S.K. 2012. Theory and Practice of Histological Tetchniques. 7th ed. Elsevier, Churchill Livingstone, p.381423.

Reis N.P. 2015. Epitelização de enxertos cutâneos em feridas recentes de coelhos tratados com membrana amniótica canina e/ou laserterapia. Master Dissertation, Universidade Estadual Paulista Júlio de Mesquita Filho, Jaboticabal, São Paulo. 48p.

Garros I.C., Campos A.C.L., Tâmbara E.M., Tenório S.B., Torres O.J.M., Agulham M.A., Araújo A.C.F., Santis-Isolan P.M.B., Oliveira R.M. \& Arruda E.C.M. 2006. Extrato de Passiflora edulis na cicatrização de feridas cutâneas abertas em ratos: estudo morfológico e histológico. Acta Cir. Bras. 21(3):55-65.

Hay F.C., Westwood O.M.R., Nelson P.N. \& Hudson L. 2002. Practical Immunology. Blackwell Science, Malden, MA.

Hedlund C.S. 2008. Cirurgia de Pequenos Animais. 3aㅡ ed. Elsevier, São Paulo. $1390 \mathrm{p}$.

Maeda K., Chung Y.S., Takatsuka S., Ogawa Y., Onoda N., Sawada T., Kato Y., Nitta A., Arimoto Y., Kondo Y. \& Sowa M. 1995. Tumor angiogenesis and tumour cell proliferation as prognostic indicador in gastric carcinoma. Brit. J. Cancer 72(2):319-323.

Pazzini J.M. \& Moraes P.C. 2015. Princípios e Técnicas de Cirurgias Reconstrutivas da Pele de Cães e Gatos: atlas colorido. Medvep, Curitiba, p.95102.

Pazzini J.M., De Nardi A.B., Huppes R.R., Gering A.P., Ferreira M.G.P.A., Silveira C.B.P., Luzzi M.C \& Santos R. 2016. Method to obtain platelet rich plasma from rabbits (Oryctolagus cuniculus). Pesq. Vet. Bras. 36(1):39-44.

Serafim E.L. 2016. Fechamento de defeitos em padrão de figura geométrica associado ao emprego de anestesia por tumescência com lidocaína em coelhos (Oryctolagus cuniculus). Master Dissertation, Universidade Estadual Paulista Júlio de Mesquita Filho, Jaboticabal, SP. 68p.

Vendramin F.S., Franco D., Nogueira C.M., Pereira M.S. \& Franco T.R. 2006. Plasma rico em plaquetas e fatores de crescimento: técnica de preparo e utilização em cirurgia plástica. Revta Col. Bras. Cir. 33:24-28.

Weidner N., Semple J.P., Welch W.R. \& Folkman J. 1991. Tumor angiogenesis and metastasis: correlation in invasive breast carcinoma. New Engl. J. Med. 324:1-8. 